Research Article

\title{
Experimental Research on Destruction Mode and Anchoring Performance of Carbon Fiber Phyllostachys pubescens Anchor Rod with Different Forms
}

\author{
Wang Yulan $\left(\mathbb{D},{ }^{1}\right.$ Dong Zhao, ${ }^{1}$ Wei Lu $\left(\mathbb{D},{ }^{1}\right.$ and Lei Fan ${ }^{2}$ \\ ${ }^{1}$ School of Civil Engineering, Xi'an University of Architecture and Technology, Xi'an 710055, China \\ ${ }^{2}$ Shaanxi Provincial Institute of Cultural Heritage, Xi'an 710075, China \\ Correspondence should be addressed to Wang Yulan; 346535527@qq.com
}

Received 12 August 2017; Accepted 31 January 2018; Published 18 March 2018

Academic Editor: Venu G. M. Annamdas

Copyright (c) 2018 Wang Yulan et al. This is an open access article distributed under the Creative Commons Attribution License, which permits unrestricted use, distribution, and reproduction in any medium, provided the original work is properly cited.

The anchoring technology is extensively applied in reinforcing protection of the earth relics. Now that no specification is available for different new anchor rods in earth relics protection due to diversified destruction modes of earth relics and complexity of engineering technology conditions, it is urgent to guide reinforcing design and construction with a complete detailed anchor rod research document. With the new carbon fiber Phyllostachys pubescens anchor rod as the research object, six lots of in situ tests are designed to, respectively, study the destruction mode and anchoring performance of the carbon fiber Phyllostachys pubescens anchor rod under different anchor length $L$, anchor rod diameter $D$, bore diameter $H$, grouting material $S$, rib spacing $R$, and inclination angle $A$ in this paper. By studying load shift curve experiment in drawing of the anchor rod, the destruction mode and ultimate bearing capacity of the carbon fiber Phyllostachys pubescens anchor rod in different experiment lots are obtained, and the concept of permitted application value $N$ in anchor rod design is proposed. By studying strain distribution characteristics of anchor rods in experimental lots along the length direction under action of the permitted application value $N$ and combining the existing destruction mode and ultimate bearing capacity, this paper analyzes influences of $L, D, H, S, R$, and $A$ on anchoring effect of the carbon fiber Phyllostachys pubescens anchor rod; gives the reasonable value range of $L, D, H$, and $R$ when the carbon fiber Phyllostachys pubescens anchor rod is used for reinforcing design of the earth relics; and provides favorable experiment basis for reinforcing design of the earth relics based on the carbon fiber Phyllostachys pubescens anchor rod.

\section{Introduction}

The anchor rod is mainly applied in two aspects in earth relics protection. First, it is used to pull and connect the new built adobe and earth relics. For possible unstable erosive area, it is the most effective protection method to build the adobe. To make the adobe and earth relics bear the force together, after repair building, the building body should be connected with the body of the relics by using an anchor rod. The connected wall features better integrity and higher rupture and vibration resistance. Second, the anchor rod is used to reinforce the structural crack in the body of the relics by using an anchor rod based on grouting [1-3].

The anchoring technology is extensively applied in reinforcing protection of earth relics. Now that no specification is available for different new anchor rods in earth relics protection due to diversified destruction modes of earth relics and complexity of engineering technology conditions, it is urgent to guide reinforcing design and construction with a complete detailed anchor rod research document $[4,5]$.

Now application problems of the anchoring technology in earth relics protection are described as follows [6-10]:

(1) Some references show that the size of the anchoring force is related to the length of the anchor rod, diameter of bore, diameter of the anchor rod, strength of the grouting body, surface state of the rod body, and inclination angle. Only influences of anchoring length and grouting body on the anchoring force are 
studied in the past anchor rod research of the earth relics.

(2) No systematic research on factors affecting anchor body stress distribution is conducted. Most experiments on the anchor rod of earth relics mainly focus on anchoring force of the anchor rod. Few researchers focus on stress distribution of the anchor rod in the earth relics, which obstructs research on application of anchoring theory in earth relics protection.

For Gaochang Ruins protection engineering, by conducting in situ experiment of the carbon fiber Phyllostachys pubescens anchor rod, this paper studies the destruction mode and anchoring performance of the anchoring body under different anchoring length $L$, anchor rod diameter $D$, bore diameter $H$, grouting material $S$, rib spacing $R$, and inclination angle $A$. Experiments are aimed to know main form and law of the deformation destruction of the anchoring body and provide favorable experiment basis for reinforcing design of the cultural earth relics based on the carbon fiber Phyllostachys pubescens anchor rod.

\section{Experiment Scheme of Carbon Fiber Phyllostachys pubescens Anchor Rod}

The Phyllostachys pubescens features long growth age, uniform materials, and small diameter change. If it is directly used as the anchor rod, both the surface friction factor and the anchoring force will be comparatively small. The anchoring is destructed mainly due to sliding between anchor rod and anchoring body, which does not facilitate stronger pull resistance of the Phyllostachys pubescens $[11,12,13]$. This paper studies carbon fiber Phyllostachys pubescens anchor rod to improve its surface friction factor by sticking the carbon fiber cloth on the surface of the Phyllostachys pubescens. Now the carbon fiber cloth is extensively applied in reinforcing engineering and features stronger durability and higher strength. It is uniformly wound on the surface of the Phyllostachys pubescens and is stuck by coating the epoxy resin (Figure 1).

2.1. Laboratory Manufacturing Process. A total of six independent experiment lots are designed, including 20 experiment teams and 3 experimental parts for each team. Six independent experimental lots are divided as follows: anchor rod length $L$ (5 teams), anchor rod diameter $D$ (3 teams), bore diameter $H$ (3 teams), grouting strength $S$ (3 teams), surface state $R$ of anchor rod ( 3 teams), and deployment angle of anchor rod (3 teams). The design parameters of the test parts are shown in Table 1.

The influences of different lots on anchoring force of the anchor rod should be considered, respectively. The field experimental conditions of each experimental lot are independent of each other. The single-factor test method is used. Influence of single factor on anchoring force is considered under same environmental conditions. Other five influence factors are not changed. Three proportioning is used for grouting body. For the strength of proportioning of the grouting body, refer to the material performance test of the grouting body.

The diameter of the Phyllostachys pubescens anchor rod will change within $\pm 3 \mathrm{~mm}$ in one experimental group, and the wall thickness changes within $\pm 1 \mathrm{~mm}$. The anchor is straight and has the same diameter in the whole length.

The $20 \mathrm{~mm}$ wide fiber is wound by three layers along the vertical direction of the anchor rod, and the spacing is identified in the test scheme. The end is wound by five layers and then is uniformly coated with epoxy resin. The epoxy resin should be soaked into the carbon fiber cloth in case of coating to closely stick the Phyllostachys pubescens. Now the anchoring tool cannot be directly imposed on the Phyllostachys pubescens anchor rod due to material restriction. When test parts are prepared, the bamboo joint should be connected and be filled with the epoxy mortar. The rebar with $14 \mathrm{~mm}$ diameter is inserted. The insertion depth is $2 / 3$ of the anchor rod length. Finally the anchoring tool is imposed onto the rebar. To increase the drawing resistance force of the rebar at the end of the anchor rod, a bamboo joint should be reserved at the exposed end in case of processing of the anchor rod (Figure 1).

The strain foil of the test anchor rod should be deployed at two ends, $1 / 4$ position, $1 / 2$ position, and $3 / 4$ position. The compensator should be deployed around the middle position. After the strain foil is stuck according to the requirements, the lead wire and shielding leads are welded with the tin. The leads are numbered from inside to outside. The installed strain foil should be protected with reliable and practicable measures. The nude part of the strain foil should be coated with the epoxy resin and wound with waterproof tape. Finally one layer of epoxy resin is coated for protection. For the experiment anchor rod diagram, refer to Figure 2. For field making, refer to Figure 3.

\subsection{Experimental Materials}

2.2.1. Mechanical Property Test of Phyllostachys Pubescens. The Phyllostachys pubescens used in the test is produced from Hunan and features long growth age, uniform quality, and small diameter change. Specimens were taken from internode sections, and the sections' dimensions were $200 \mathrm{~mm}$ $((L$, longitudinal $) \times 20 \mathrm{~mm}(T$, tangential $))$ and the thickness was about $5 \mathrm{~mm}$ [14] (Figure 4).

Three groups of sample parts are, respectively, prepared. The rate of water content of the bamboo is about $11.5 \%$. The tensile test (Figure 5) and bending test (Figure 6) are performed to test the tensile strength parallel to grain, tensile elasticity modulus parallel to grain, bending strength parallel to grain, and bending elastic modulus parallel to grain [15-17]. The test results are shown in Tables 2-5.

\subsubsection{Dynamic Performance Test of Adobe and Rammed} Earth. The Gaochang Ruins wall body (Figure 7) is mainly built by rammed earth. The core sample is drilled in the in situ test area to test the material parameters shown in Table 6. 


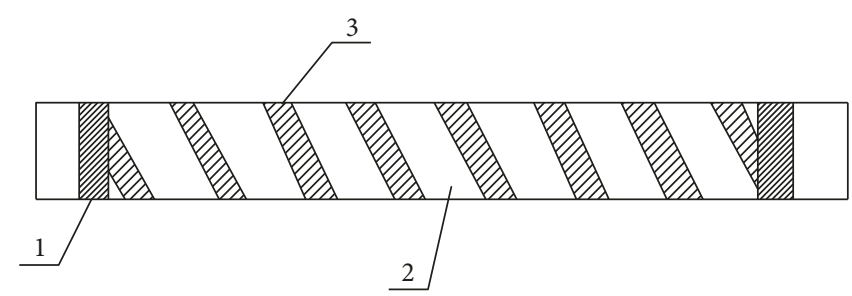

Figure 1: Carbon fiber Phyllostachys pubescens anchor rod. (1) Five-layer carbon fiber; (2) Phyllostachys pubescens; (3) three-layer carbon fiber.

TABLE 1: Design parameter of each specimen grouping.

\begin{tabular}{|c|c|c|c|c|c|c|c|}
\hline \multirow[b]{2}{*}{ Factor } & \multicolumn{7}{|c|}{ Parameter } \\
\hline & $\begin{array}{l}\text { Anchor rod } \\
\text { length (mm) }\end{array}$ & $\begin{array}{c}\text { Anchor rod } \\
\text { diameter }(\mathrm{mm})\end{array}$ & $\begin{array}{l}\text { Bore diameter } \\
(\mathrm{mm})\end{array}$ & $\begin{array}{l}\text { Grouting } \\
\text { number }\end{array}$ & $\begin{array}{l}\text { Fiber winding } \\
\text { distance }(\mathrm{mm})\end{array}$ & $\begin{array}{l}\text { Deployment angle } \\
\text { of anchor rod }\end{array}$ & $\begin{array}{c}\text { The number or } \\
\text { anchor rod }\end{array}$ \\
\hline \multirow{5}{*}{$L$ (anchor rod length) } & 800 & \multirow{5}{*}{33} & \multirow{5}{*}{85} & \multirow{5}{*}{ N1 } & \multirow{5}{*}{75} & \multirow{5}{*}{$0^{\circ}$} & 3 \\
\hline & 1200 & & & & & & 3 \\
\hline & 1500 & & & & & & 3 \\
\hline & 2000 & & & & & & 3 \\
\hline & 3000 & & & & & & 3 \\
\hline \multirow{3}{*}{$D$ (anchor rod diameter) } & \multirow{3}{*}{1500} & 25 & \multirow{3}{*}{85} & \multirow{3}{*}{ N1 } & \multirow{3}{*}{75} & \multirow{3}{*}{$0^{\circ}$} & 3 \\
\hline & & 35 & & & & & 3 \\
\hline & & 55 & & & & & 3 \\
\hline \multirow{3}{*}{$H$ (bore diameter) } & \multirow{3}{*}{1500} & \multirow{3}{*}{33} & 75 & \multirow{3}{*}{ N1 } & \multirow{3}{*}{75} & \multirow{3}{*}{$0^{\circ}$} & 3 \\
\hline & & & 85 & & & & 3 \\
\hline & & & 110 & & & & 3 \\
\hline \multirow{3}{*}{$S$ (grouting strength) } & \multirow{3}{*}{1500} & \multirow{3}{*}{33} & \multirow{3}{*}{85} & N1 & \multirow{3}{*}{75} & \multirow{3}{*}{$0^{\circ}$} & 3 \\
\hline & & & & $\mathrm{N} 2$ & & & 3 \\
\hline & & & & $\mathrm{N} 3$ & & & 3 \\
\hline \multirow{3}{*}{$R$ (surface state) } & \multirow{3}{*}{1500} & \multirow{3}{*}{33} & \multirow{3}{*}{85} & \multirow{3}{*}{ N1 } & 0 & \multirow{3}{*}{$0^{\circ}$} & 3 \\
\hline & & & & & 30 & & 3 \\
\hline & & & & & 150 & & 3 \\
\hline \multirow{3}{*}{$\begin{array}{l}\text { A (deployment angle } \\
\text { of anchor rod) }\end{array}$} & \multirow{3}{*}{1500} & & & & & $0^{\circ}$ & 3 \\
\hline & & 33 & 85 & N1 & 75 & $10^{\circ}$ & 3 \\
\hline & & & & & & $15^{\circ}$ & 3 \\
\hline
\end{tabular}

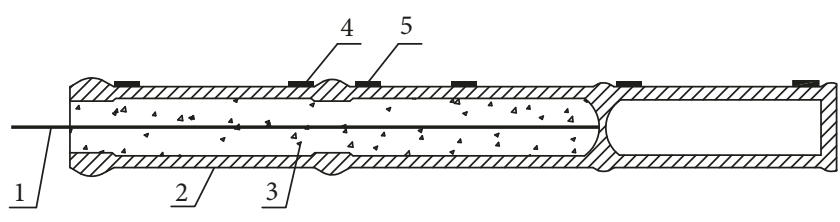

Figure 2: The experiment anchor rod diagram. (1) Rebar; (2) Phyllostachys pubescens; (3) epoxy mortar; (4) strain foil; (5) compensator.

2.2.3. Dynamic Performance Test of Grouting Body. Proportion three grouting bodies according to the actual engineering experiences. The grouting body proportioning is calculated by the weight proportioning [10].

No. 1 grouting body proportioning: earth: cement: flyash $=85: 5: 10.5 \%$ ludox emulsion is mixed.

No. 2 grouting body proportioning: earth: cement: flyash $=80: 10: 10.5 \%$ sweller is used.

No. 3 grouting body proportioning: earth: cement: flyash $=70: 20: 10.5 \%$ sweller emulsion is mixed.

The ratio of water to ash of the three slurries is $31 \%$ (weight ratio). The $70.7 \times 70.7 \mathrm{~mm}$ mortar test die is used to make the grouting test block. After 34-day maintenance, its compressive mechanical performance is shown in Table 7.

\section{In Situ Test}

The west section of the rampart in the Gaochang Ruins is selected as the experimental section. The drawing resistance test of the anchor rod is performed on the rammed earth wall relics. The whole process is completed at the construction field. The geological conditions are same as those of the reinforcing objects.

3.1. Installation of Test Parts. Drilling is performed according to the test scheme. Vibration-free machinery is used for 


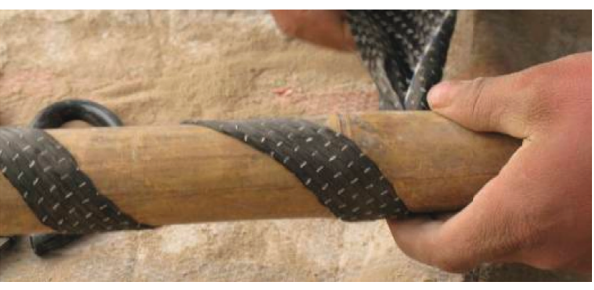

(a)

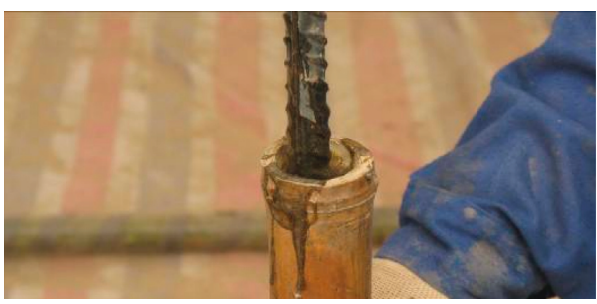

(c)

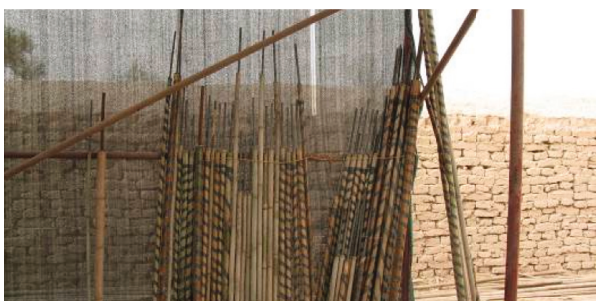

(e)

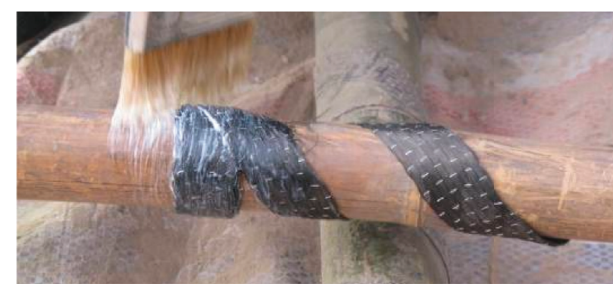

(b)

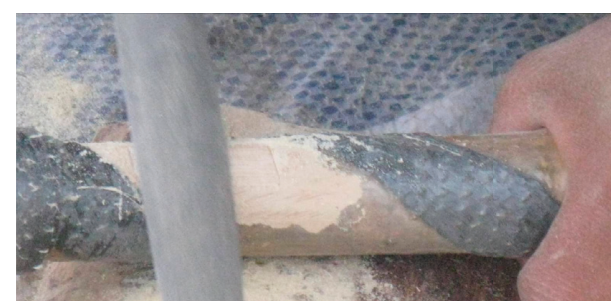

(d)

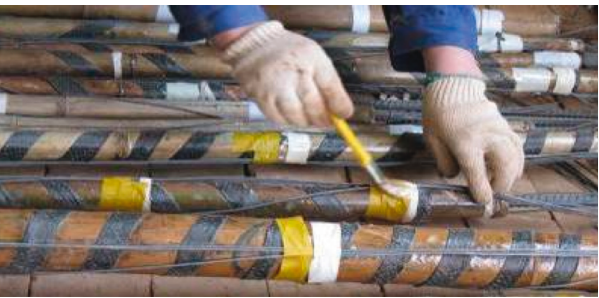

(f)

Figure 3: The manufacture of the experiment anchor rod.

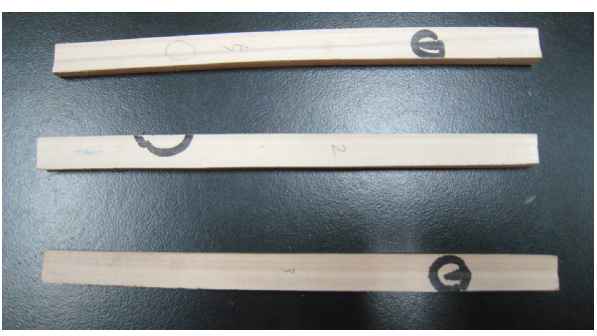

Figure 4: The specimens of bamboo.

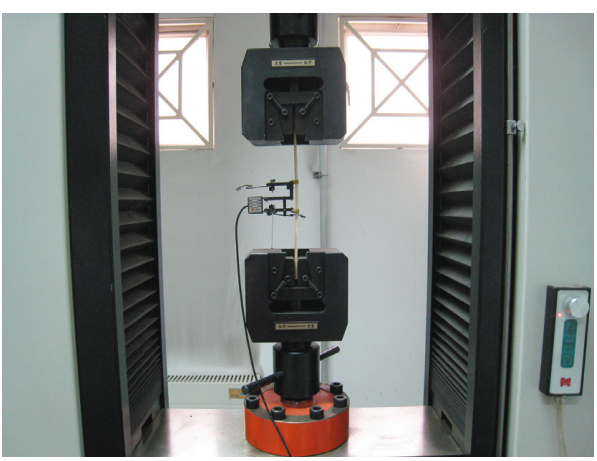

Figure 5: The extension test.

drilling. The vertical and horizontal spacing between holes is more than $1 \mathrm{~m}$ to avoid mutual influences. Protective supports should be used to secure relics and persons.

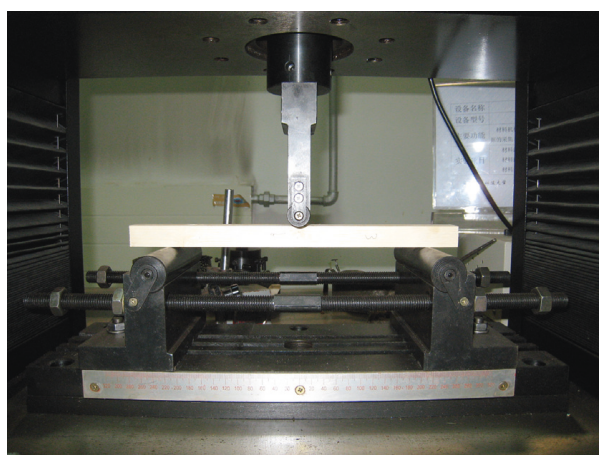

Figure 6: The bending test.

Clean bore diameter and moisture it prior to grouting. Clean the bore diameter by using an electric blower's peripheral bushing, and moisture it with soft brush and small sprinkler.

Place the grouting pipe and anchor rod into the bore simultaneously, remotely transport grouting with a hose, and avoid vibration influences of grouting machinery. The distance from the grouting pipe end to bore bottom should be $100 \mathrm{~mm}$.

The grouting pressure of the grouter is $0.5 \mathrm{MPa}$. The grouting should be grouted densely. $100 \mathrm{~mm}$ deep grouting materials (modified loess grouting) are used for grouting and anchoring at two ends of the bore. The field anchoring test parts are shown in Figure 8. The structure of the anchor rod is shown in Figure 9. 
TABLE 2: The tensile strength along the grain of the bamboo material.

\begin{tabular}{lccc}
\hline $\begin{array}{l}\text { Specimen } \\
\text { number }\end{array}$ & $\begin{array}{c}\text { Moisture } \\
\text { content }\end{array}$ & $\begin{array}{c}\text { The tensile strength } \\
\text { along the grain }(\mathrm{MPa})\end{array}$ & $\begin{array}{c}\text { The average } \\
\text { value (MPa) }\end{array}$ \\
\hline BS1 & $11.2 \%$ & 304.9 & \\
BS2 & $11.8 \%$ & 309.7 & 314.1 \\
BS3 & $12.3 \%$ & 327.6 & \\
\hline
\end{tabular}

TABLE 3: The tensile elasticity modulus along the grain of the bamboo material.

\begin{tabular}{lccc}
\hline $\begin{array}{l}\text { Specimen } \\
\text { number }\end{array}$ & $\begin{array}{c}\text { Moisture } \\
\text { content }\end{array}$ & $\begin{array}{c}\text { Tensile elasticity modulus } \\
\text { along the grain } 10^{4}(\mathrm{MPa})\end{array}$ & $\begin{array}{c}\text { The average } \\
\text { value } 10^{4} \\
(\mathrm{MPa})\end{array}$ \\
\hline BSE1 & $12.1 \%$ & 3.80 & \\
BSE2 & $11.3 \%$ & 3.91 & 3.83 \\
BSE3 & $11.6 \%$ & 3.78 & \\
\hline
\end{tabular}

TABle 4: The flexural strength along the grain of the bamboo material.

\begin{tabular}{lccc}
\hline $\begin{array}{l}\text { Specimen } \\
\text { number }\end{array}$ & $\begin{array}{c}\text { Moisture } \\
\text { content }\end{array}$ & $\begin{array}{c}\text { The flexural strength } \\
\text { along the grain }(\mathrm{MPa})\end{array}$ & $\begin{array}{c}\text { The average } \\
\text { value }(\mathrm{MPa})\end{array}$ \\
\hline BB1 & $11.5 \%$ & 213.9 & \\
BB2 & $11.4 \%$ & 217.6 & 214.6 \\
BB3 & $11.8 \%$ & 212.2 & \\
\hline
\end{tabular}

TABLe 5: The flexural modulus along the grain of the bamboo material.

\begin{tabular}{lccc}
\hline $\begin{array}{l}\text { Specimen } \\
\text { number }\end{array}$ & $\begin{array}{c}\text { Moisture } \\
\text { content }\end{array}$ & $\begin{array}{c}\text { The flexural modulus } \\
\text { along the grain } 10^{4} \\
(\mathrm{MPa})\end{array}$ & $\begin{array}{c}\text { The average } \\
\text { value } 10^{4} \\
(\mathrm{MPa})\end{array}$ \\
\hline BBW1 & $12.5 \%$ & 1.5897 & \\
BBW2 & $11.3 \%$ & 1.5634 & 1.5814 \\
BBW3 & $11.8 \%$ & 1.5912 & \\
\hline
\end{tabular}

3.2. Test Method. The ZY-10 anchor rod tension meter from Chinese Coal Science Research Institute is used as the dynamometer (Figure 10(a)). The measurement range is 0 $100 \mathrm{kN}$, and the pulling force stroke is $150 \mathrm{~mm}$. The TDS-303 data collection instrument from Japan is used as the strain collector (Figure 10(b)) with a measurement range of $-20,000$ to 20,000 . The KFG general strain foil is selected. The sensitive grating is $3 \times 10 \mathrm{~mm}$ (the resistance is $120.8 \pm$ 0.1 and sensitivity is $2.14 \pm 1 \%$ ). The SMT at the middle of the anchor rod is set as the temperature compensator. Other SMT is the data collection point. To match the tensile strength tester of the anchor rod, $2 \mathrm{~cm}$ thick steel plate is used to make the reaction frame. The wood block is used for padding between the reaction frame and relics (Figure 10 (a)). The shift sensor is installed on the steel reaction frame. The experimental device is shown in Figure 11.

The experiment was performed in Gaochang Ruins, Turpan, Sinkiang. After the grouting body is fully solidified (about 50 days), the in situ drawing test is performed for the embedded anchor rod due to experimental place and weather factor.

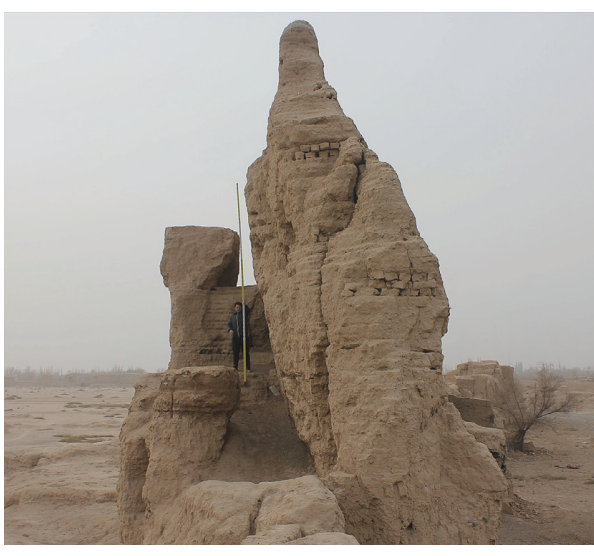

FIgURE 7: Gaochang Ruins wall: a view.

TABLE 6: Physical and mechanical parameters of rammed earth.

\begin{tabular}{lccccc}
\hline $\begin{array}{l}\text { Test } \\
\text { lock }\end{array}$ & $\begin{array}{c}\text { Moisture } \\
\text { content, } \\
\omega(\%)\end{array}$ & $\begin{array}{c}\text { Density, } \\
\left(\mathrm{g} \cdot \mathrm{cm}^{-3}\right)\end{array}$ & $\begin{array}{c}\text { Angle of } \\
\text { internal } \\
\text { friction, } \\
\varphi\left(^{\circ}\right)\end{array}$ & $\begin{array}{c}\text { Cohesion } \\
\text { strength, } c \\
(\mathrm{kN})\end{array}$ & $\begin{array}{c}\text { Elastic } \\
\text { modulus, } \\
E(\mathrm{MPa})\end{array}$ \\
\hline 1 & 3.1 & 1.76 & 25.1 & 28.3 & 17.94 \\
2 & 2.9 & 1.82 & 24.8 & 29.2 & 18.88 \\
3 & 2.4 & 1.85 & 23.5 & 25.5 & 20.03 \\
Average & 2.8 & 1.81 & 24.4 & 27.67 & 18.95 \\
\hline
\end{tabular}

$500 \mathrm{~N}$ pulling force is first applied prior to loading to eliminate the force gap between devices. The pulling force is slowly and continuously applied. $200 \mathrm{~N}$ force is applied per second till the test part is destructed $[10,18]$.

\section{Analysis on Test Results}

4.1. Analysis on Destruction Mode and Ultimate Anchoring Force. Arrange experimental data, observe and record experimental phenomena, and get the drawing destruction mode and ultimate anchoring force in different experimental groups shown in Tables 8-13.

4.1.1. Analysis on the Final Destruction Mode. As could be seen from the experimental results, there were four types of anchorage system failure: anchor pullout (Figure 12(a)), grout-soil interface damage (Figure 12(b)), anchor-end split (Figure 12(c)), and soil-part loosening (Figure 12(d)).

(a) Most cases fell into the category of "anchor pullout." This was mainly due to the anchor-grout interface sliding owing to the insufficiently high anchoring force against the grout generated by relatively short anchors.

(b) The anchoring force is relatively big, and the shift is small in case of grout-soil interface damage. The force of the anchoring system is fully exerted. Based on analysis on the force, the grout-soil interface damage is an ideal destruction mode of the anchoring system, though it should not occur in relics protection. 
TABLE 7: The mechanical performance of the grouting.

\begin{tabular}{|c|c|c|c|c|c|}
\hline \multirow{2}{*}{ Test block } & \multirow{2}{*}{ Number } & \multicolumn{2}{|c|}{ Compression strength (MPa) } & \multicolumn{2}{|c|}{ Compression elastic modulus $10^{5}(\mathrm{MPa})$} \\
\hline & & Experimental value & Average & Experimental value & Average \\
\hline \multirow{3}{*}{ No. 1} & 1 & 1.94 & \multirow{3}{*}{1.92} & 62.35 & \multirow{3}{*}{61.26} \\
\hline & 2 & 1.83 & & 55.66 & \\
\hline & 3 & 1.98 & & 65.78 & \\
\hline \multirow{3}{*}{ No. 2} & 1 & 1.81 & \multirow{3}{*}{1.84} & 67.95 & \multirow{3}{*}{68.38} \\
\hline & 2 & 1.82 & & 68.04 & \\
\hline & 3 & 1.90 & & 69.14 & \\
\hline \multirow{5}{*}{ No. 3} & 1 & 6.54 & \multirow{5}{*}{6.28} & 178.8 & \multirow{5}{*}{178.5} \\
\hline & 2 & 6.02 & & 168.3 & \\
\hline & 3 & 6.27 & & 188.4 & \\
\hline & 2 & 6.02 & & 168.3 & \\
\hline & 3 & 6.27 & & 188.4 & \\
\hline
\end{tabular}

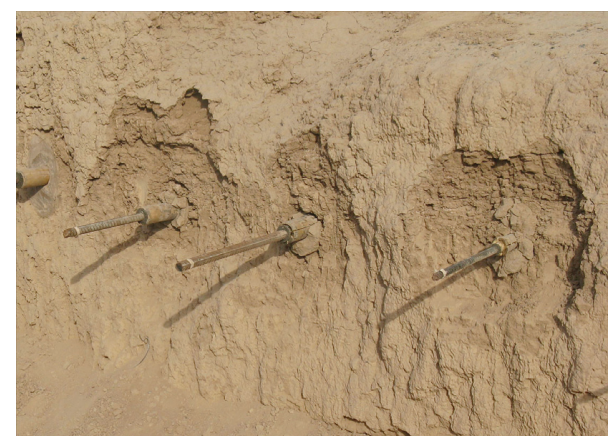

FIgURE 8: The field anchoring test parts.

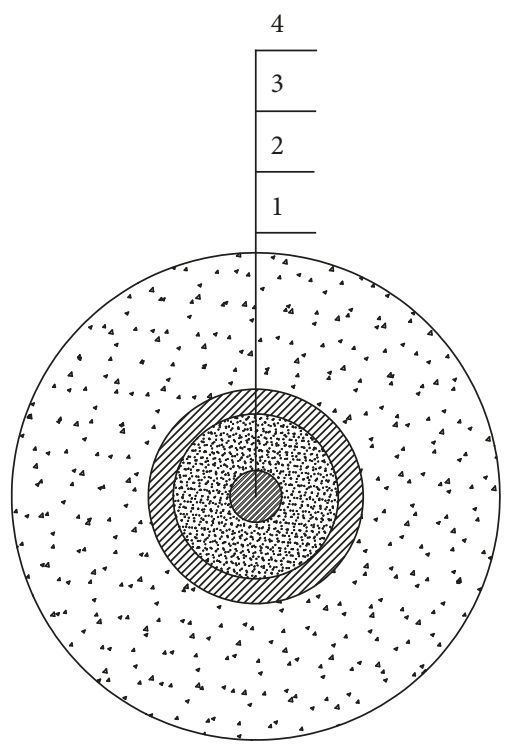

Figure 9: The structure of the anchor rod. (1) Rebar; (2) epoxy mortar; (3) Phyllostachys pubescens; (4) grouting.

(c) The anchor-end split and the epoxy rebar are drawn out. This destruction is caused because the inner wall of Phyllostachys pubescens is smooth, and friction force between the high-strength epoxy resin grouting and inner wall of Phyllostachys pubescens cannot resist higher external drawing force. Rupture of the

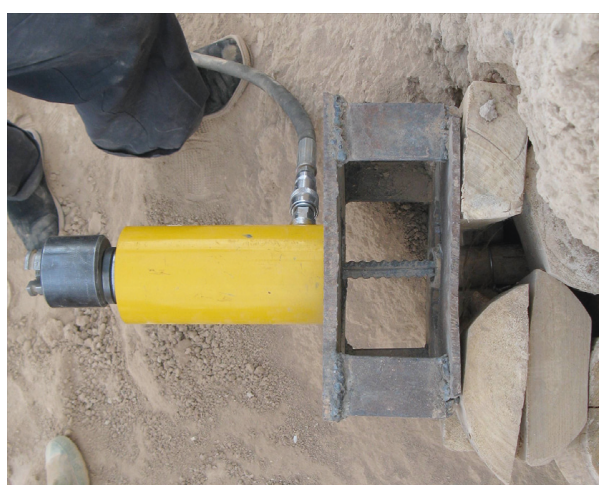

(a)

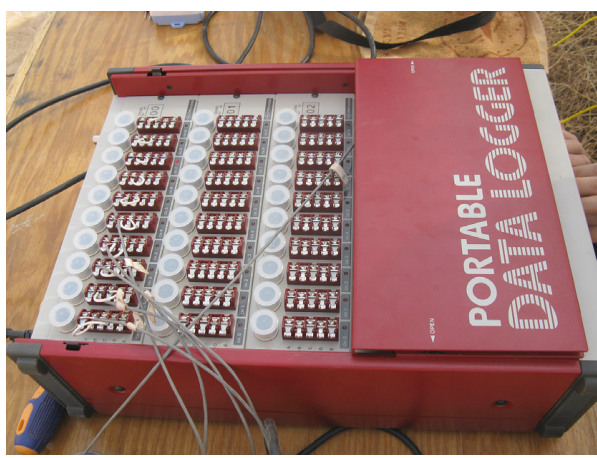

(b)

Figure 10: Test apparatus. (a) Pullout apparatus and the reaction frame. (b) The TDS-303 data collection instrument.

anchor rod end cannot indicate that the anchoring system is ineffective. The anchor rod end is wound tightly by using three rounds of steel wires to improve the fastening force between the concrete iron and Phyllostachys pubescens in the experiment, which has better effect in the experiment.

(d) Soil-part loosening is due to visible crackles that appear in the earth around the grouting. This destruction only happens at two places in the experiment and is related to the earth characteristics of the anchoring position. The earth characteristics of the anchoring part should be fully considered in anchoring design of the earth relics, which should be excessively intervened. 


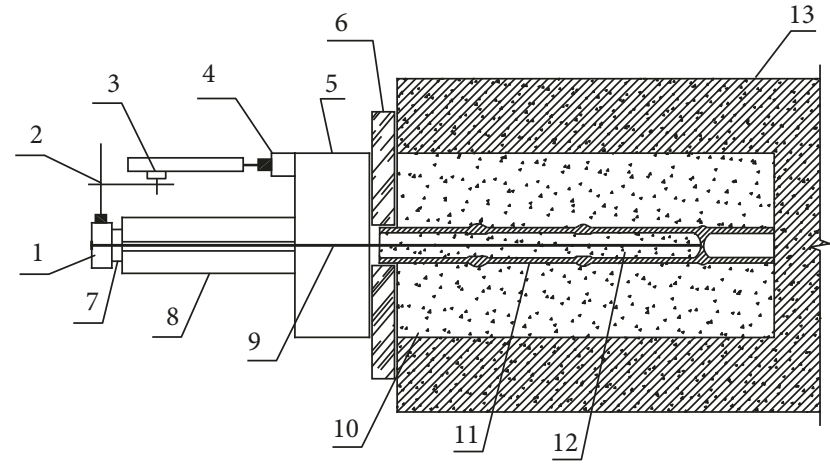

FIgURE 11: The experimental device diagram. (1) Anchorage; (2) magnetic stand; (3) displacement sensor; (4) support displacement sensor; (5) reaction frame; (6) wood footplate; (7) load sensor; (8) hollow jack; (9) rebar; (10) grouting; (11) Phyllostachys pubescens; (12) epoxy mortar; (13) site soil.

TABle 8: The test results by different anchor rod length.

\begin{tabular}{lccc}
\hline Number & Destruction mode & $\begin{array}{c}\text { Fracture } \\
\text { load }(\mathrm{kN})\end{array}$ & $\begin{array}{c}\text { Average } \\
(\mathrm{kN})\end{array}$ \\
\hline L8-1 & Anchor pullout & 12.3 & \\
L8-2 & Anchor pullout & 12.6 & 12.45 \\
L8-3 & Anchor-end split, rebar slip & $8.3^{*}$ & \\
\hline L12-1 & Anchor pullout & 15.5 & \\
L12-2 & Anchor pullout & 14.2 & 14.85 \\
L12-3 & Anchor-end split, rebar slip & $12.2^{*}$ & \\
\hline L15-1 & Anchor pullout & 19.6 & \\
L15-2 & Anchor pullout & 17.2 & 18.47 \\
L15-3 & Anchor pullout & 18.6 & \\
\hline L20-1 & Anchor pullout & 29.7 & \\
L20-2 & Anchor pullout & 33.5 & 31.60 \\
L20-3 & Anchor-end split, rebar slip & $22.4^{*}$ & \\
\hline L30-1 & Soil-part loosening & $30.6^{*}$ & \\
L30-2 & Anchor pullout & 43.5 & \multirow{2}{*}{45.90} \\
L30-3 & Anchor-end split, grout-soil & 48.3 & \\
& interface damage & &
\end{tabular}

*The data are not considered.

TABLE 9: The test results by different anchor rod diameter.

\begin{tabular}{|c|c|c|c|}
\hline Number & $\begin{array}{l}\text { Destruction } \\
\text { mode }\end{array}$ & $\begin{array}{l}\text { Fracture load } \\
(\mathrm{kN})\end{array}$ & $\begin{array}{c}\text { Average } \\
(\mathrm{kN})\end{array}$ \\
\hline D25-1 & Anchor pullout & 10.5 & \multirow{3}{*}{11.53} \\
\hline D25-2 & Anchor pullout & 12.8 & \\
\hline D25-3 & Anchor pullout & 11.2 & \\
\hline D35-1 & Anchor pullout & 18.7 & \multirow{3}{*}{17.50} \\
\hline D35-2 & Anchor pullout & 17.6 & \\
\hline D35-3 & Anchor pullout & 16.2 & \\
\hline D55-1 & $\begin{array}{l}\text { Anchor-end split, } \\
\text { anchor pullout }\end{array}$ & 18.4 & \multirow{3}{*}{21.23} \\
\hline D55-2 & Anchor pullout & 23.6 & \\
\hline D55-3 & Anchor pullout & 21.7 & \\
\hline
\end{tabular}

The destruction modes are not separate in the experiment. Generally multiple destruction forms happen in the process from initial drawing of the anchoring system to final destruction. The destruction with bigger shift of the anchoring system should be regarded as the final destruction.
TABLE 10: The test results by different bore diameter.

\begin{tabular}{lccc}
\hline Number & Destruction mode & $\begin{array}{c}\text { Fracture } \\
\text { load }(\mathrm{kN})\end{array}$ & $\begin{array}{c}\text { Average } \\
(\mathrm{kN})\end{array}$ \\
\hline H75-1 & Anchor pullout & 15.5 & \\
H75-2 & $\begin{array}{c}\text { Anchor-end split, grout-soil } \\
\text { interface damage }\end{array}$ & $14.2^{*}$ & 16.65 \\
H75-3 & Anchor pullout & 17.8 & \\
\hline H85-1 & Anchor-end split, anchor pullout & 20.3 & \\
H85-2 & Anchor pullout & 19.7 & 18.70 \\
H85-3 & Anchor pullout & 16.1 & \\
\hline H110-1 & Anchor pullout & 26.5 & \\
H110-2 & Grout-part loosening & $18.8^{*}$ & 24.9 \\
H110-3 & Anchor-end split, & 23.3 & \\
& anchor pullout & & \\
\hline
\end{tabular}

${ }^{*}$ The data are not considered.

TABLE 11: The test results by different grouting strength.

\begin{tabular}{lccc}
\hline Number & Destruction mode & Fracture load $(\mathrm{kN})$ & Average $(\mathrm{kN})$ \\
\hline S1-1 & Anchor-end split & $9.4^{*}$ & \\
S1-2 & Anchor pullout & 15.1 & 16.15 \\
S1-3 & Anchor pullout & 17.2 & \\
\hline S2-1 & Anchor pullout & 17.6 & \\
S2-2 & Anchor pullout & 16.2 & 16.40 \\
S2-3 & Anchor pullout & 15.4 & \\
\hline S3-1 & Anchor pullout & 15.9 & 17.20 \\
S3-2 & Anchor pullout & 17.5 & \\
S3-3 & Anchor pullout & 18.2 & \\
\hline
\end{tabular}

${ }^{*}$ The data are not considered.

TABLE 12: The test results by different surface state.

\begin{tabular}{lccc}
\hline Number & Destruction mode & Fracture load $(\mathrm{kN})$ & Average $(\mathrm{kN})$ \\
\hline R0-1 & Anchor pullout & 11.2 & \\
R0-2 & Anchor pullout & 9.4 & 9.77 \\
R0-3 & Anchor pullout & 8.7 & \\
\hline R75-1 & Anchor pullout & 15.9 & \\
R75-2 & Anchor pullout & 19.6 & 17.23 \\
R75-3 & Anchor pullout & 16.2 & \\
\hline R150-1 & Anchor pullout & 14.3 & 13.43 \\
R150-2 & Anchor pullout & 13.2 & \\
R150-3 & Anchor pullout & 12.8 & \\
\hline
\end{tabular}

\subsubsection{Analysis on Ultimate Anchoring Force.}

(a) By analyzing the $L, D$, and $H$ experimental results, we can know that the geometric size of the anchoring system is sensitive to the ultimate anchoring force.

From the macroview, bigger anchoring system will lead to bigger ultimate anchoring force, but too big geometric size will lead to local destruction of the anchoring system, in which case the anchoring system cannot fully realize anchoring and the body of the relics will be destructed.

$15 \mathrm{~m}$ long $\varphi 35 \mathrm{~mm}$ anchor rod with $85 \mathrm{~mm}$ diameter anchoring hole is reasonable relatively.

(b) From the experimental results of $R$ series, if the rib is applied on the surface of the anchor rod, the 
TABLE 13: The test results by different deployment angle of anchor rod.

\begin{tabular}{lccc}
\hline Number & Destruction mode & $\begin{array}{c}\text { Fracture } \\
\text { load }(\mathrm{kN})\end{array}$ & $\begin{array}{c}\text { Average } \\
(\mathrm{kN})\end{array}$ \\
\hline A0-1 & Anchor pullout & 19.3 & \\
$\mathrm{~A} 0-2$ & Anchor pullout & 17.2 & 17.76 \\
$\mathrm{~A} 0-3$ & Anchor pullout & 16.8 & \\
\hline A10-1 & Soil-part loosening & $10.4^{*}$ & \\
A10-2 & Anchor pullout & 15.8 & 16.25 \\
A10-3 & Anchor pullout & 16.7 & \\
\hline A15-1 & Anchor-end split, grout-soil & $9.2^{*}$ & \\
A15-2 & interface damage & 14.7 & 14.95 \\
A15-3 & Anchor pullout & 15.2 & \\
\hline
\end{tabular}

${ }^{*}$ The data are not considered.

ultimate anchoring force will be increased significantly. Consequently, ribbing can be taken as an effective measure to increase ultimate anchoring force.

(c) From experimental results of $S$ and $A$ series, the strength of grouting body and deployment angle of the anchor rod are not sensitive to the ultimate anchoring force. Improved strength of the grouting body can increase the ultimate anchoring force within a small range and is not the best means.

Increased anchoring deployment angle will reduce the ultimate anchoring force because the pulling force is perpendicular to the wall while the anchor rod is not perpendicular to the wall in the experiment, leading to press rupture of local earth around the anchor rod and early exit of the anchoring system.

It is not preferential to horizontally deploy the anchor in actual application. The deployment angle of the anchor rod is designed according to the force of the anchored body to keep the action line of the anchoring force coincide with the action line of the sliding force as much as possible (Figure 12).

4.2. Relation between Load Shift $(P-S)$. By removing bad values in experiment groups and averaging experimental results, we can get the P-S load shift curve of $L, D, H, R, S$, and $A$ (Figures 13-18).

(1) Influences of anchoring length $L$ on load shift.

The L-P-S curve (Figure 13) shows that increase of the anchor rod length will significantly increase the anchoring force of the anchor rod and effectively control shift of the anchor rod under same pulling force.

(2) Influences of anchoring diameter $D$ on load shift.

The D-P-S curve (Figure 14) shows that increased diameter of the anchor rod can effectively increase the anchoring force of the anchor rod, but too big bore diameter will destruct the earth relics. Compared to D35, D55 increases by $57.1 \%$, but the maximal anchoring force only increases by $19.8 \%$. The increased bore diameter cannot effectively control the shift.
(3) Influences of bore diameter $H$ on load shift

The H-P-S curve (Figure 15) shows that although the increased bore diameter can improve the anchoring force, it cannot effectively control shift. Increased bore diameter will destruct the relic body much in practical engineering.

(4) Influences of grouting body strength $S$ on load shift

The S-P-S curve (Figure 16) shows that the increased grouting body strength can effectively increase the anchoring force of the anchor rod. The shift of S1 anchor rod end is twice the S3 anchor rod end under same pulling force $P=4 \mathrm{kN}$, so the increased grouting body strength can effectively control the shift.

(5) Influences of anchor rod surface state $R$ on load shift

The R-P-S curve (Figure 17) shows that the maximal anchoring force of the anchor rod R0 without a rib is $9.77 \mathrm{kN}$. The maximal anchoring force of R150 and R75 with a rib is $13.43 \mathrm{kN}$ and $17.23 \mathrm{kN}$. The ultimate anchoring force increases by $37.46 \%$ and $76.35 \%$ after a rib is added. After the pulling force reaches $5 \mathrm{kN}$, the shift of the anchor rod end with a rib is significantly less than that of the anchor rod without a rib.

It indicates that change of anchor rod surface state can effectively increase the ultimate anchoring force and control the shift. By analyzing the destruction mode in Section 4.1, if the anchor rod surface is too coarse, destruction between the grouting and earth body will be caused, which is unfavorable to relics protection. As a result, the influence of this factor should be considered in practical design; that is, the anchor rod surface should not be designed too coarsely.

(6) Influences of anchoring deployment angle $A$ on load shift

The A-P-S curve (Figure 18) shows that the anchoring force of the anchor rod will reduce with increase of the angle and the shift will increase under the same load. The drawing force and pulling force of the anchor rod are not on one action line, so the anchoring system is destructed in advance.

4.3. Strain Distribution $(\xi-L)$ Characteristics of Anchor RodGrouting Interface. The destruction results show that generally the anchoring system is ineffective when the pulling force reaches the ultimate load, the anchoring system has no visible destruction symptom, and the anchor rod is suddenly drawn out. Sufficient security preparations should be made when the anchor rod technology is used in design due to significance of relics protection engineering. The anchoring system should be on the elastic phase. By combining practical applications, $30 \%$ of the ultimate load $M$ should be selected as the permitted application value $N(N=30 \% \mathrm{XM})$.

Six experimental lots $(L, D, H, S, R$, and $A)$ are prepared to study strain distribution characteristics of the rod bodygrouting interface in different experimental lots on the elasticity phase in this paper. After the experimental data are arranged, the permitted application value $N$ of different experimental lots $(L, D, H, S, R$, and $A)$ is shown in Table 14 . 


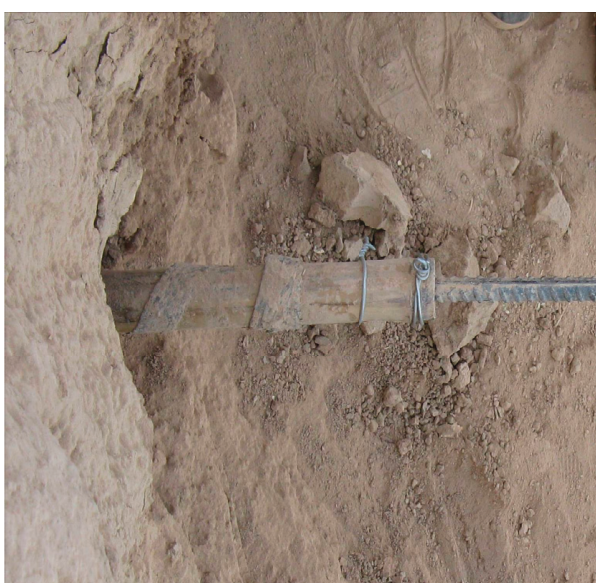

(a)

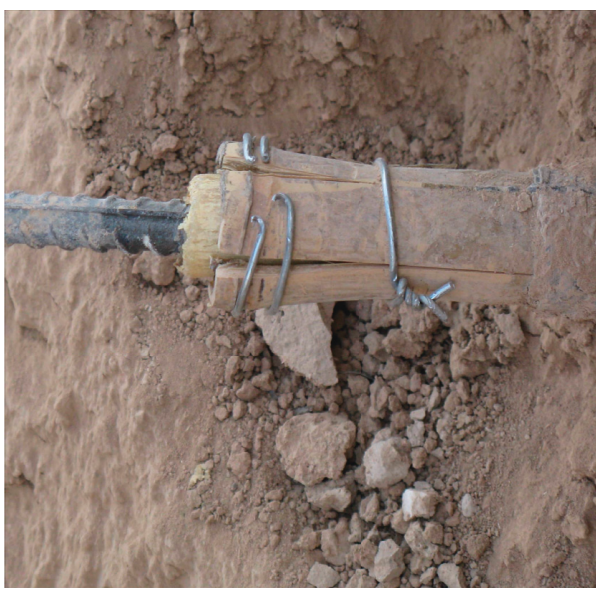

(c)

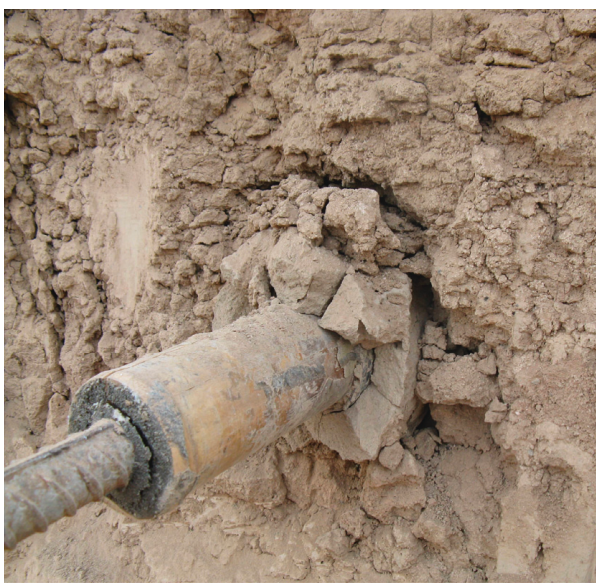

(b)

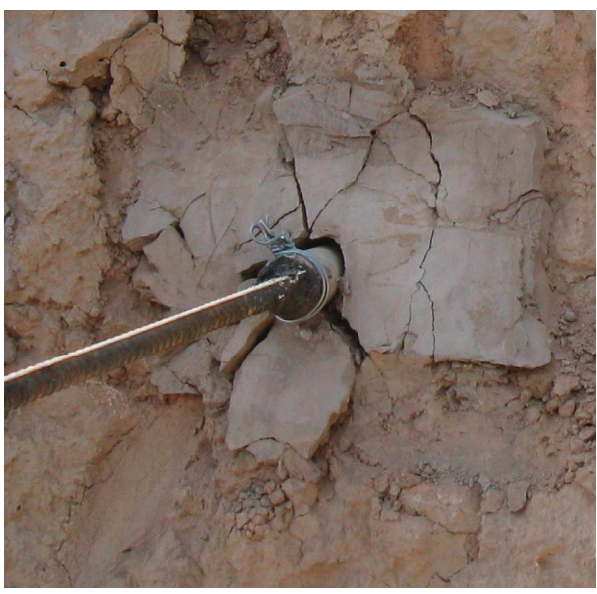

(d)

FIgURE 12: The main destruction mode. (a) Anchor pullout. (b) Grout-soil interface damage. (c) Anchor-end split. (d) Soil-part loosening.

L-P-S

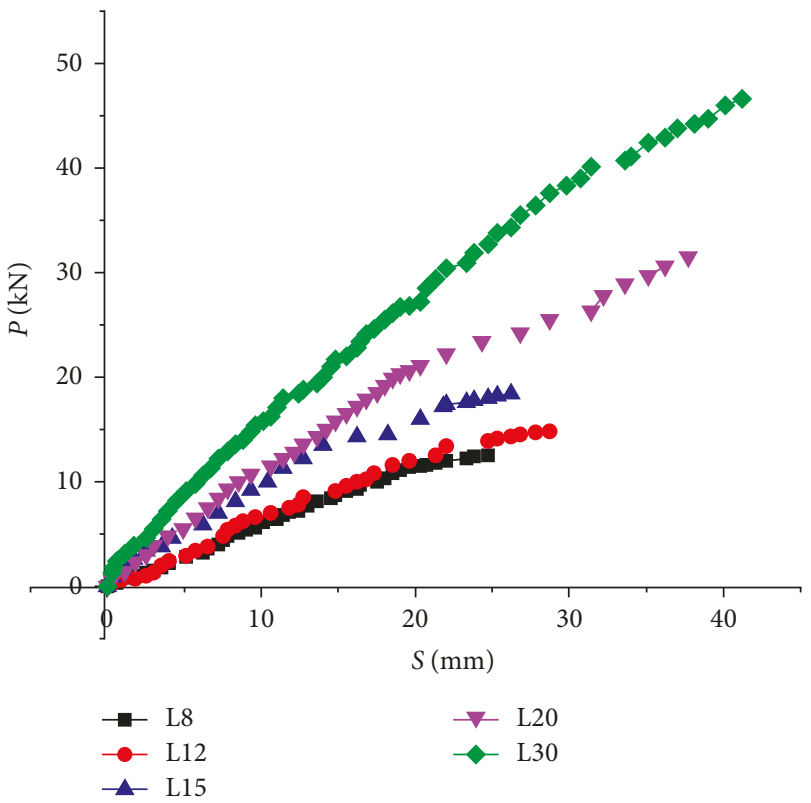

FIgUre 13: The curve of L-P-S.
D-P-S

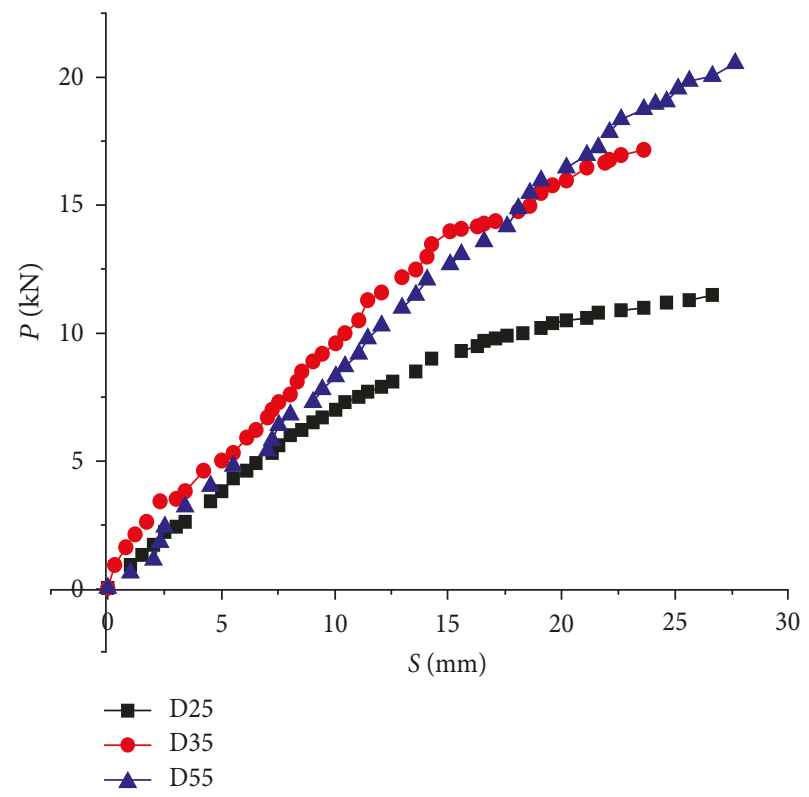

Figure 14: The curve of D-P-S. 


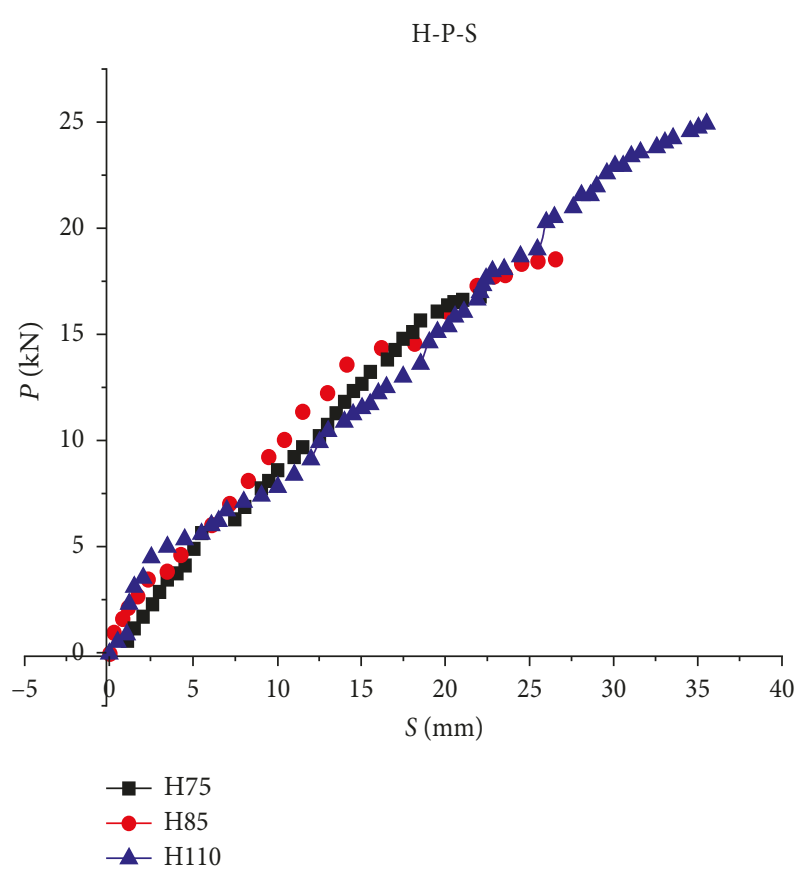

Figure 15: The curve of H-P-S.

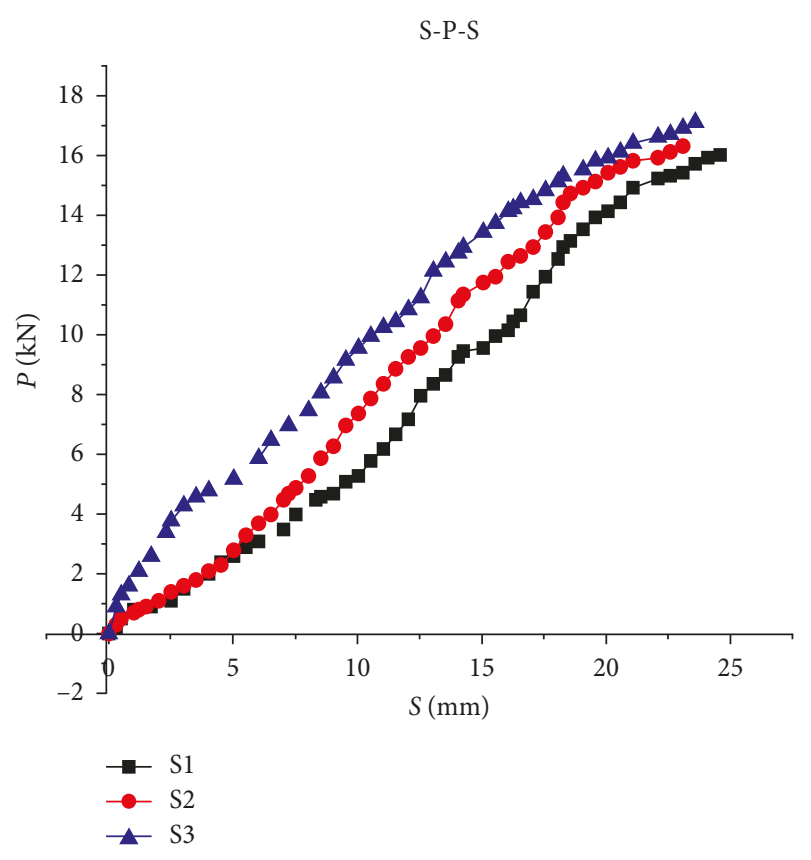

Figure 16: The curve of 16 S-P-S.

We can get strain distribution curve (Figures 19-24) of rod body-grouting interface under the permitted application value $N_{i}$ in each experimental lot $(L, D, H, R, S$, and $A$ ).

(1) Influences of anchor rod length $L$ on strain distribution of anchor rod-grouting interface

The $L-\xi-L$ curve (Figure 19) shows that the maximal transmission depth of the anchoring force is about $2 \mathrm{~m}$ under the permitted application value $N_{i}$. When the anchoring length is $800 \mathrm{~mm}$, the stress distribution of the

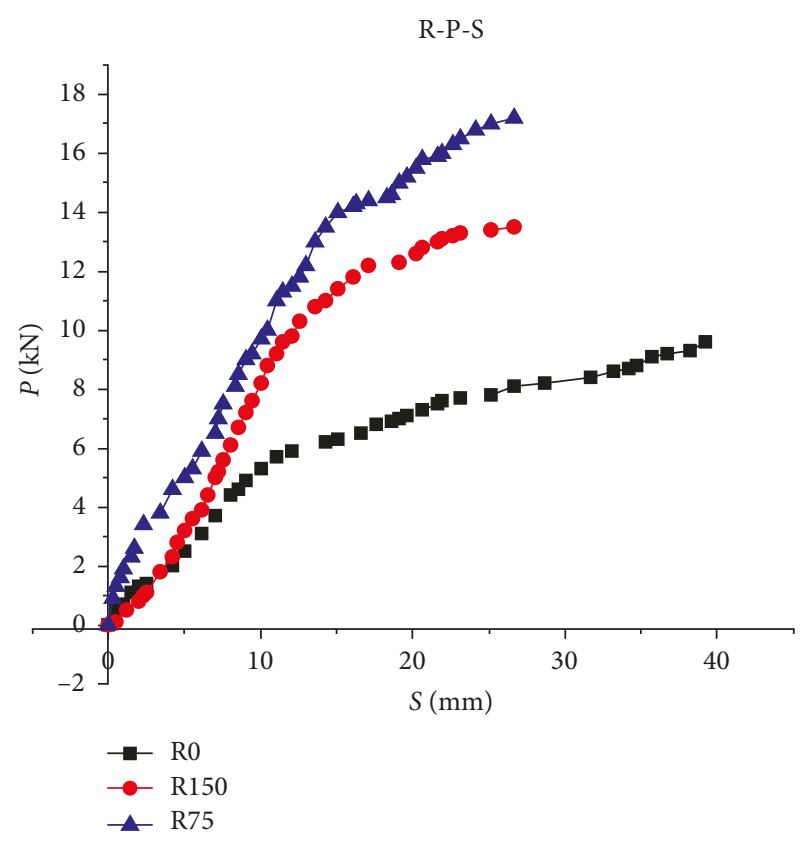

Figure 17: The curve of R-P-S.

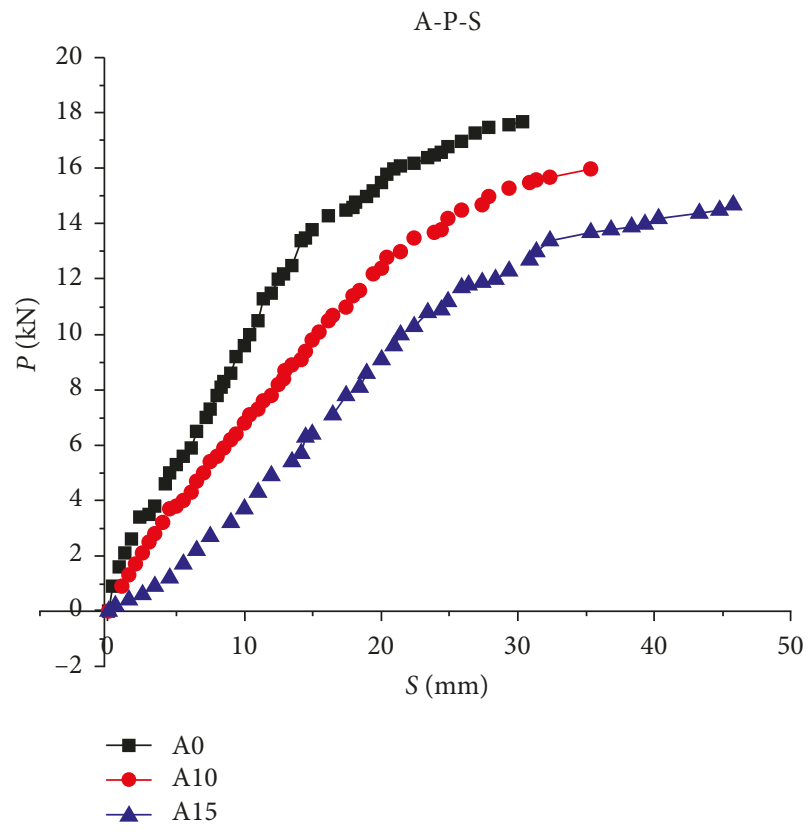

Figure 18: The curve of A-P-S.

anchor rod is not uniform and the stress change of the middle section is big. When the anchoring length is $1200 \mathrm{~mm}$ and $1500 \mathrm{~mm}$, the stress distribution is relatively uniform. When the anchoring length is $2000 \mathrm{~mm}$ and $3000 \mathrm{~mm}$, the stress on the start section of the anchor rod will uniformly change and the stress distribution is mild on the latter half section.

On the whole, longer anchor length indicates more uniform stress distribution and smaller adjacent strain change under action of the permitted application value $N$. The strain value of the anchoring section is smaller after $2 \mathrm{~m}$. 
TABLE 14: The permitted application value $N(\mathrm{kN})$.

\begin{tabular}{lccccccccccc}
\hline$L$ & $N_{i}(\mathrm{kN})$ & $D$ & $N_{i}(\mathrm{kN})$ & $H$ & $N_{i}(\mathrm{kN})$ & $S$ & $N_{i}(\mathrm{kN})$ & $R$ & $N_{i}(\mathrm{kN})$ & $A$ & $N_{i}(\mathrm{kN})$ \\
\hline L8 & 3.72 & D25 & 3.46 & H75 & 5.00 & S1 & 4.85 & R0 & 2.93 & A0 & 5.33 \\
L12 & 4.46 & D35 & 5.25 & H85 & 5.61 & S2 & 4.92 & R150 & 4.03 & A10 & 4.88 \\
L15 & 5.54 & D55 & 6.37 & H110 & 7.47 & S3 & 5.16 & R75 & 5.17 & A15 & 4.49 \\
L20 & 9.3 & - & - & - & - & - & - & - & - & - & - \\
L30 & 13.77 & - & - & - & - & - & - & - & - & - \\
\hline
\end{tabular}

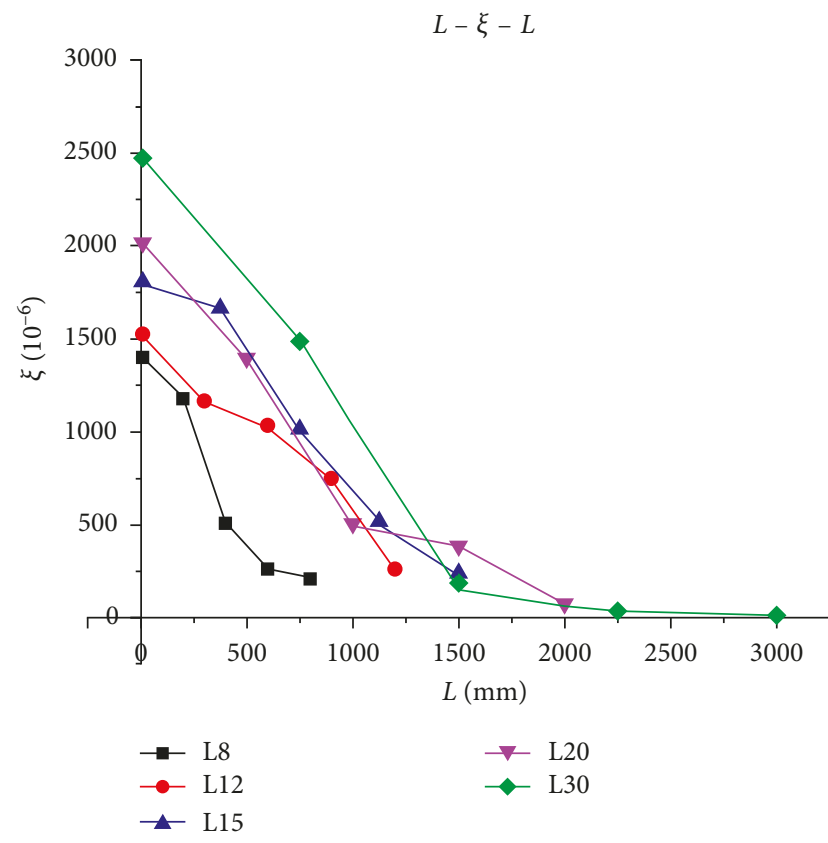

FIgURE 19: The curve of $L-\xi-L$.

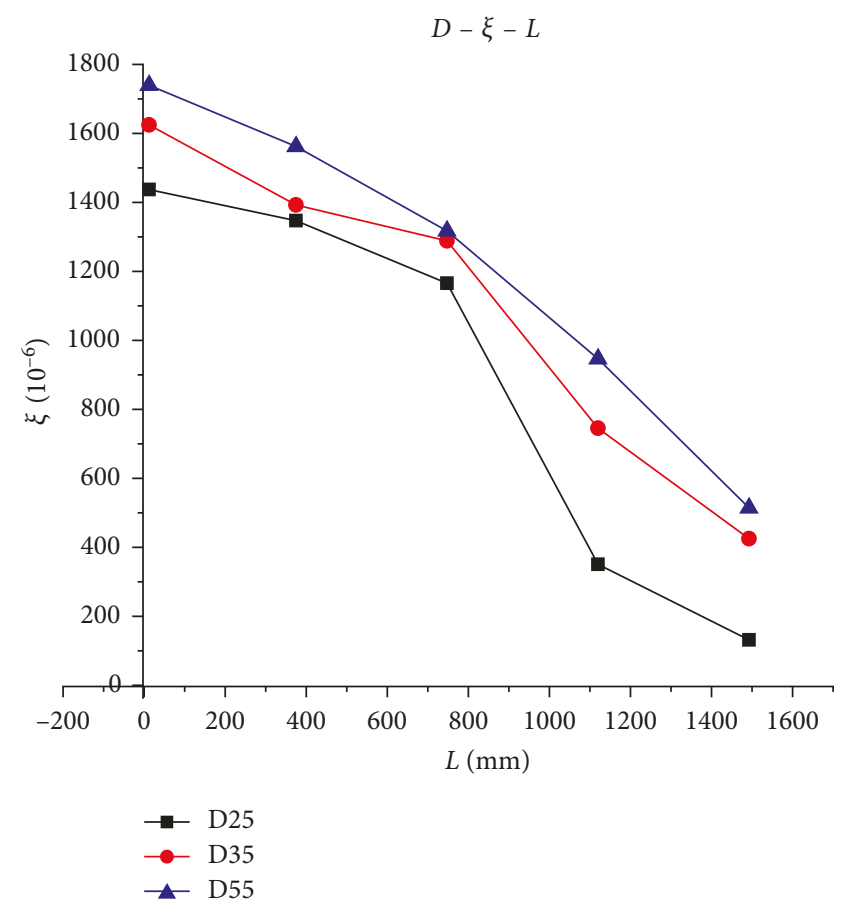

Figure 20: The curve of $D-\xi-L$.

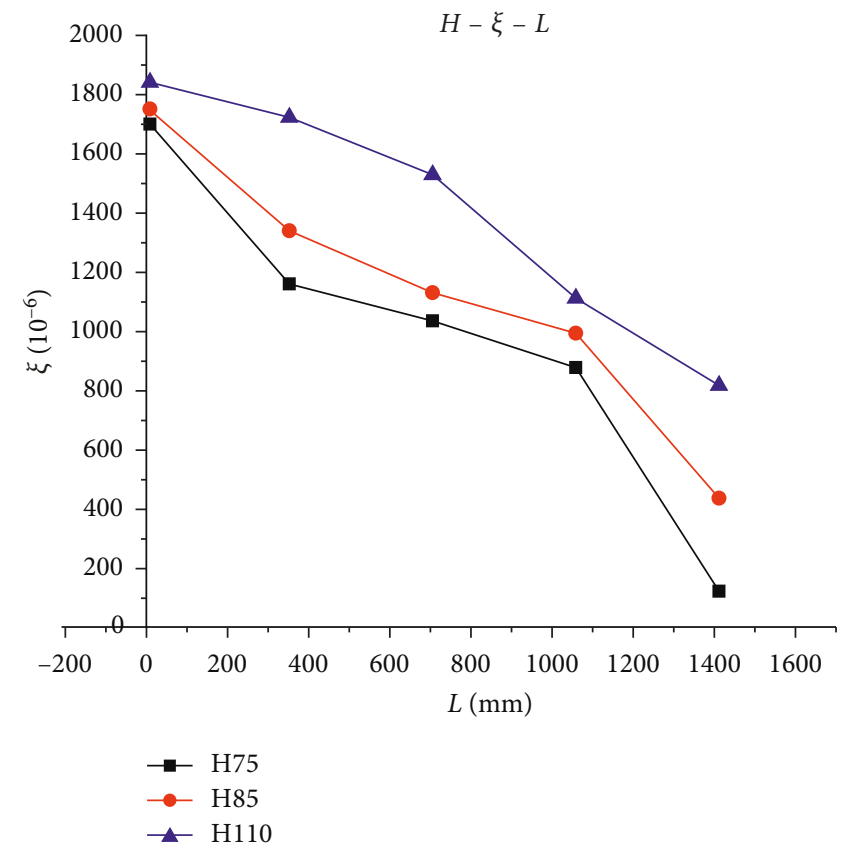

Figure 21: The curve of $H-\xi-L$.

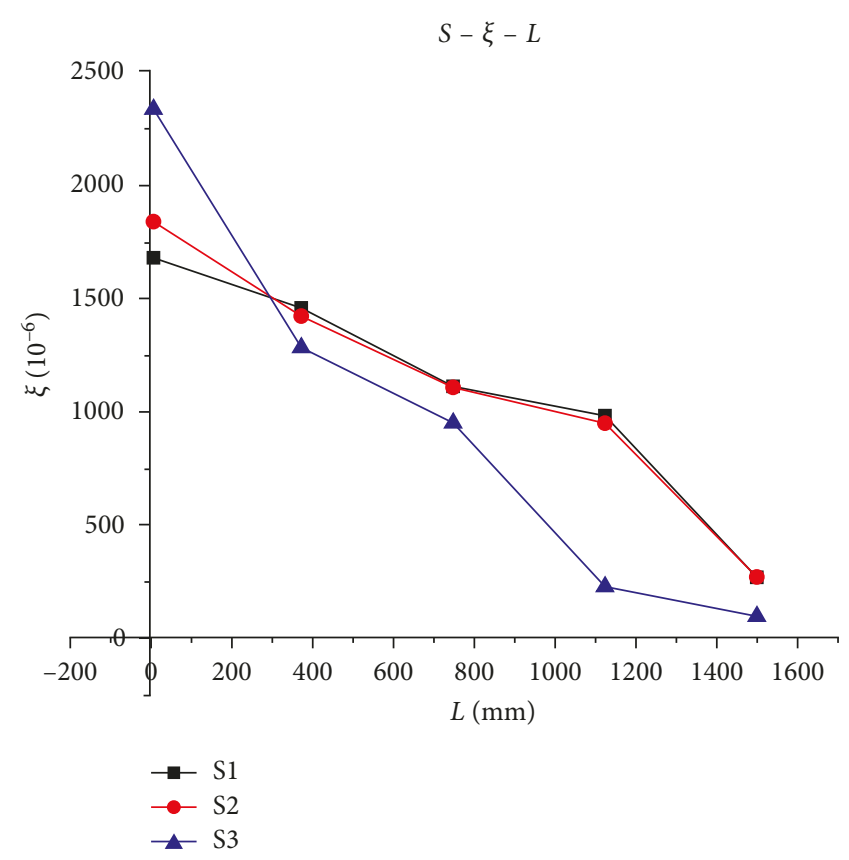

Figure 22: The curve of $S-\xi-L$. 


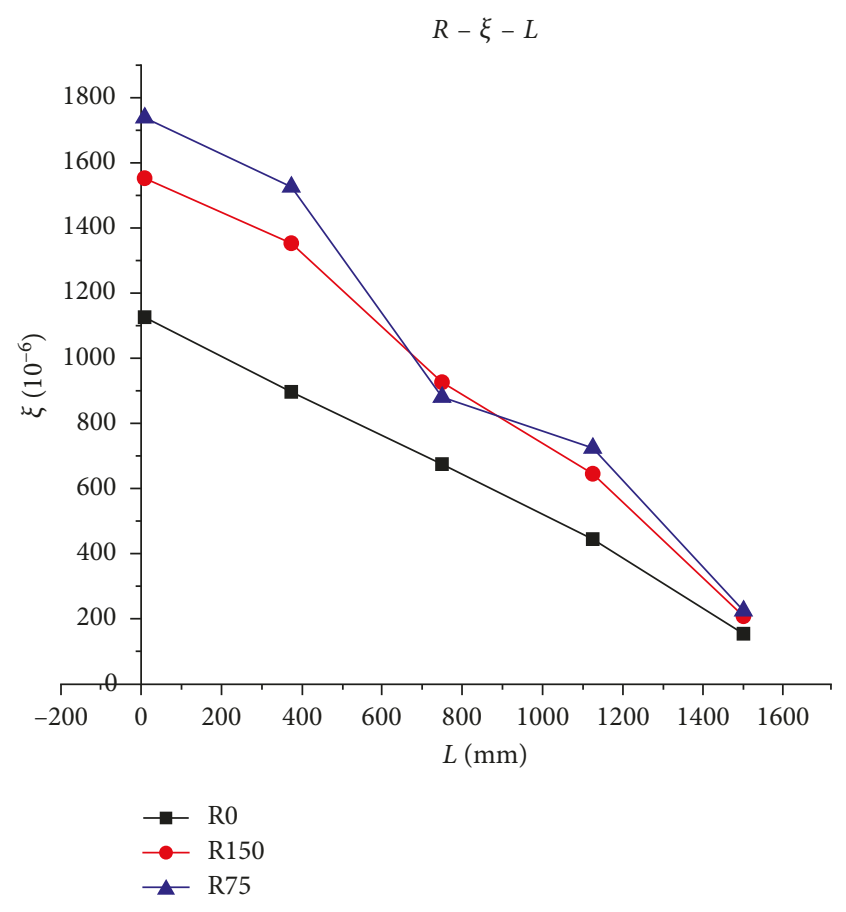

Figure 23: The curve of $R-\xi-L$.

The maximal transmission depth of the anchoring force is about $2 \mathrm{~m}$. The designed anchoring depth should not be more than $2 \mathrm{~m}$ when the anchor rod is designed according to the permitted application standard. The most effective anchoring length is between $1.2 \mathrm{~m}$ and $1.5 \mathrm{~m}$.

(2) Influences of anchoring diameter $D$ on strain distribution of rod body-grouting interface

The $D-\xi-L$ curve (Figure 20) shows that the bigger diameter of the anchoring rod indicates more uniform stress distribution under action of the permitted application value $N_{i}$.

The pulling and shearing action is the main factor to destruct the anchor rod in the pulling force anchor rod. Based on the above test conclusion, the bigger diameter of the anchoring body is preferred, so the shear stress on the anchoring body can be uniform. The diameter of the anchoring body cannot be increased without a limitation due to influences of material properties of the grouting body. When the diameter increases to certain extent, its contribution to the ultimate anchoring force is not significant.

(3) Influences of bore diameter $H$ on strain distribution of rod body-grouting interface

The $H-\xi-L$ curve (Figure 21) shows that the stress distribution of the anchoring body is prone to uniformity with growth of the bore diameter to facilitate strain dispersion under action of the permitted application value $N_{i}$.

(4) Influences of grouting body strength $S$ on strain distribution of rod body-grouting body interface

The $S-\xi-L$ curve (Figure 22) shows that the rod body strain distribution is prone to nonuniformity and that the

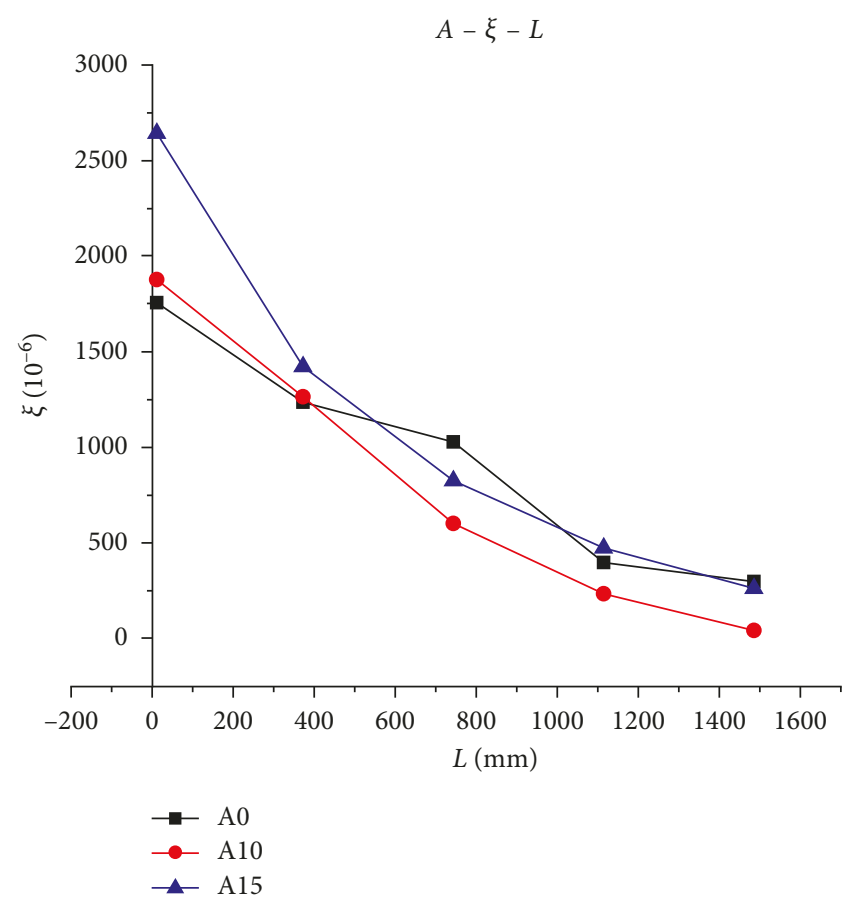

Figure 24: The curve of $A-\xi-L$.

peak strain becomes bigger with growth of the grouting material strength under action of the permitted application value $N_{i}$. If the strength of the grouting material is properly improved under certain conditions, it can improve the anchoring force, but the stress distribution is prone to nonuniformity.

(5) Influences of the anchor rod surface state $R$ on strain distribution of rod body-grouting body interface

The $R-\xi-L$ curve (Figure 23) shows that the peak strain of the anchor rod will increase and the strain distribution is more centralized with reduction of the surface rib spacing of the anchor rod under action of permitted application value $N_{i}$, so the small rib spacing is not always preferred. The recommended rib spacing of the carbon fiber Phyllostachys pubescens anchor rod is $60 \sim 80 \mathrm{~mm}$ in the earth relics reinforcing protection.

(6) Influences of anchoring deployment angle $A$ on strain distribution of rod body-grouting interface

The $A-\xi-L$ curve (Figure 24) shows that the peak strain of the anchor rod will increase with growth of the angle, which is closely associated with experimental conditions. The deployment angle of the anchor rod should be reasonably designed in practical applications to ensure that the anchoring force and sliding force action line of the anchored solid are on one line.

\section{Conclusions and Recommendations}

The following conclusions can be concluded from in situ drawing experiment of the anchor rod of the rammed earth relics: 
(1) The destruction does not separately happen in the experiment. When the anchoring system is drawn till final destruction, generally multiple destruction forms will be accompanied. The anchoring system mainly becomes ineffective due to debonding and sliding between the anchor rod and grouting body interface and shift between grouting body and earth body, and rupture of pipe hole grouting body and earth relics body cutting and expansion are accompanied.

The anchoring force is bigger, and the shift is smaller in case of destruction between the grouting body and earth body, so the force of the anchoring system is fully exerted. This destruction is an ideal destruction mode from the view of mechanics, but this destruction form is unfavorable to relics protection. Draw-out destruction of the anchor rod is favorable to protection over the earth relics body.

We recommend that anchorage strength should not be the sole factor for consideration in designing anchoring systems for earthen heritage sites. Characteristics of the earthen fabric around the drive-in point are also to be taken into full accounts. It is essential that a site itself is protected and the minimum intervention principle is observed.

(2) Bigger $L, D$, and $H$ parameter of the anchoring system indicates higher ultimate anchoring force. If the ultimate anchoring force is too high, before the anchoring system exits from operation, it will lead to local destruction of the earth relics and destruct the body of the relics. Higher earth strength and smaller diameter of the anchor rod indicate higher shear stress on the anchor rod and is more unfavorable to earth reinforcing.

For earthen heritage sites with higher strength, shorter and thicker anchor piles are required while for those with lower strength, longer and thinner ones. Piles could thus function more effectively in load bearing. As the analysis of the rammed earth of Gaochang city walls revealed, parameters $L, D$, and $H$ for anchor piles should be set as, respectively, $1200-1500 \mathrm{~mm}, 35-55 \mathrm{~mm}$, and $1.5-2.5 \mathrm{~mm}$.

(3) The $S$ series experiments show that the grouting body strength is not sensitive to the ultimate anchoring force. If the grouting body strength is improved within a small range, it can improve the ultimate anchoring force, but it leads to nonuniform strain distribution of the anchor rod.

Therefore for the anchoring system, performance enhancing is not advisable to be achieved by an increase of strength in the grout body. For the rammed earth of Gaochang city walls, grout body S2 has been proved suitable for anchoring needs.

(4) The $R$ series experiments indicate that change of anchor rod surface state can effectively improve the ultimate anchoring force and control the shift.

With decrease of the rib spacing on the surface of the anchor rod, the peak strain of the anchor rod will increase and the strain distribution becomes centralized. If the surface of the anchor rod is too coarse, it will lead to destruction between the grouting body and earth body and is unfavorable to relics protection.

The surfaces of anchor piles, fashioned of Phyllostachys pubescens, should not be too uneven. For the rammed earth of Gaochang city walls, a proper rib-interval is calculated at 60-80 mm.

(5) The $A$ series experiments indicate that the deployment angle of the anchor rod should be reasonably designed in practicable applications to ensure that the anchoring force and the sliding force of the anchored body keep on one line.

A qualitative stability analysis for a site is advised to precede anchor pile designing. Potential surfaces of failure could thus be located to inform the design and installation processes.

\section{Conflicts of Interest}

The authors declare that they have no conflicts of interest.

\section{Acknowledgments}

This study was sponsored by the Youth Science and Technology Fund of Xi'an University of Architecture \& Technology, Xi'an, China (Grant no. QN1531), and Fund of Shaanxi Province Education Department (Grant no. 16JK1430). In the preparation of the paper, the authors hold gratitude for Mr. Xi Lin for his suggestions in proofreading and English wording.

\section{References}

[1] Z. Dong, M. Xiaofei, and C. Ping, "Research on reinforcement of earthen architecture site with geo-filament anchor," Chinese Industrial Construction, vol. 38, no. 1, pp. 114-116, 2008.

[2] M.-L. Sun, "Research status and development of the conservation of earthen sites," Science of Conservation and Archeology, vol. 19, no. 4, pp. 64-69, 2007.

[3] G. Li, L. Gao, Z. Huang, and D. Zhang, "Pull-out model experiment on failure mechanism of full-length bonding glass fiber reinforced polymer rebar," Chinese Journal of Rock Mechanics and Engineering, vol. 26, no. 8, pp. 1653-1663, 2007.

[4] E. A. Ahmed, E. F. El-Salakawy, and B. Benmokrane, "Tensile capacity of GFRP postinstalled adhesive anchors in concrete," Journal of Composite for Construction, vol. 12, no. 6, pp. 596-607, 2008.

[5] B. Zhang, B. Benmokrane, A. Usama, and A. Ebead, "Design and evaluation of fiber-reinforced polymer bond-type anchorages and ground anchors," International Journal of Geomechanics, vol. 6, no. 3, pp. 166-175, 2006.

[6] H.-D. Liu, X.-Z. Yu, and G.-W. Li, "Experimental study on tensile mechanical properties of glass fiber reinforced plastic rebar," Chinese Journal of Rock Mechanics and Engineering, vol. 24, no. 20, pp. 3719-3723, 2005.

[7] M.-L. Sun, X.-D. Wang, Z.-X. Li, and L. Zhang, "Study on immature earthen sites reinforced with wood anchor," Chinese Journal of Geotechnical Engineering, vol. 28, no. 12, pp. 2156-2159, 2006.

[8] Z. Wu, S. Yang, J. Zheng, and X. Hu, "Analytical solution for the pull-out response of FRP rods embedded in steel tubers filled with cement grout," Material and Structures, vol. 43, no. 5, pp. 597-609, 2010. 
[9] F. F. Ren, Z. J. Yang, J. F. Chen, and W. W. Chen, “An analytical analysis of the full-range behaviour of grouted rockbolts based on a tri-linear bond-slip model," Construction and Building Materials, vol. 24, pp. 361-370, 2010.

[10] B. Benmokrane, B. Zhang, and A. Chennouf, "Tensive properties and pullout behaviour of AFRP and CFRP rods for grouted anchor applications," Construction and Building Materials, vol. 14, no. 3, pp. 157-170, 2000.

[11] S. C. Lakkad and J. M. Patel, "Mechanical properties of bamboo, a natural composite," Fibre Science and Technology, vol. 14, no. 4, pp. 319-322, 1981.

[12] Y. Wang and D. Zhao, "The deterioration inspection and cause analysis for Ming-Jing Tai," Electronic Journal of Geotechnical Engineering, vol. 21, no. 7, pp. 1659-1680, 2016.

[13] S. Chuma, M. Hirohashi, T. Ohgama, and Y. Kasahara, "Composite structure and tensile properties of mousou bamboo," Journal of the Society of Materials Science, Japan, vol. 39, no. 442, pp. 847-851, 1990.

[14] Z.-P. Shao, C.-H. Fang, and G.-L. Tian, "Mode I interlaminar fracture property of moso bamboo (Phyllostachys pubescens)," Wood Science and Technology, vol. 45, no. 5-6, pp. 527-536, 2009.

[15] E. Obataya, P. Kitin, and H. Yamauchi, "Bending characteristics of bamboo (Phyllostachys pubescens) with respect to its fiber-foam composite structure," Wood Science and Technology, vol. 41, no. 5, pp. 385-400, 2007.

[16] M. Ahmad and F. A. Kamke, "Analysis of Calcutta bamboo for structural composite materials. Physical and mechanical properties," Wood Science and Technology, vol. 39, no. 6, pp. 448-459, 2005.

[17] Z.-P. Shao, C.-H. Fang, S.-X. Huang, and G.-L. Tian, "Tensile properties of Moso bamboo (Phyllostachys pubescens) and its components with respect to its fiber-reinforced composite structure," Wood Science and Technology, vol. 44, no. 4, pp. 655-666, 2010.

[18] R. S. Merifield and S. W. Sloan, "The ultimate pullout capacity of anchors in frictional soils," Canadian Geotechnical Journal, vol. 43, no. 8, pp. 852-868, 2006. 


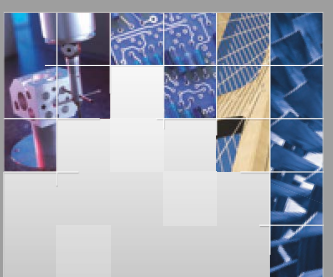

\section{Enfincering}
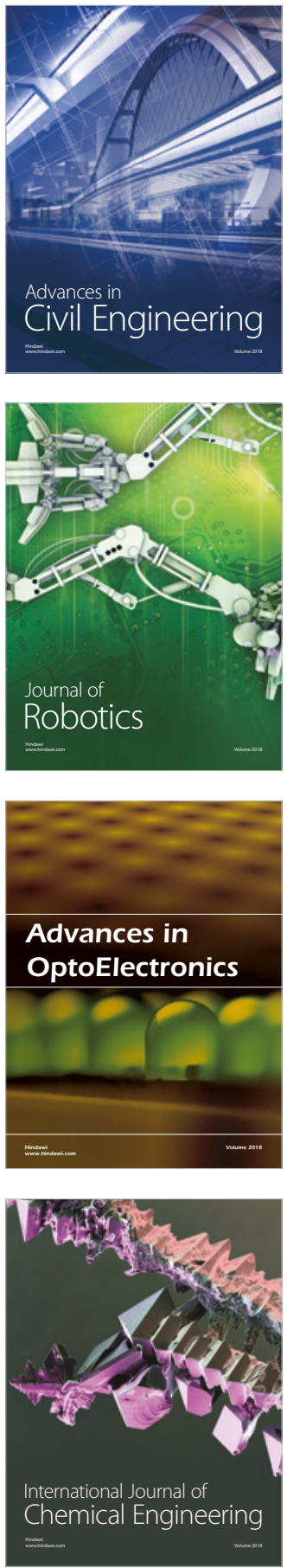

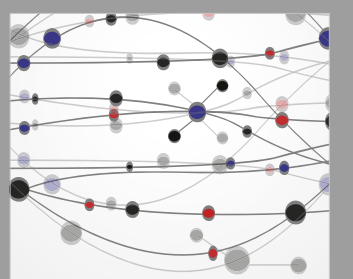

\section{Rotating \\ Machinery}

The Scientific World Journal

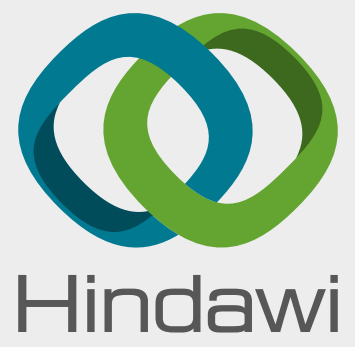

Submit your manuscripts at

www.hindawi.com
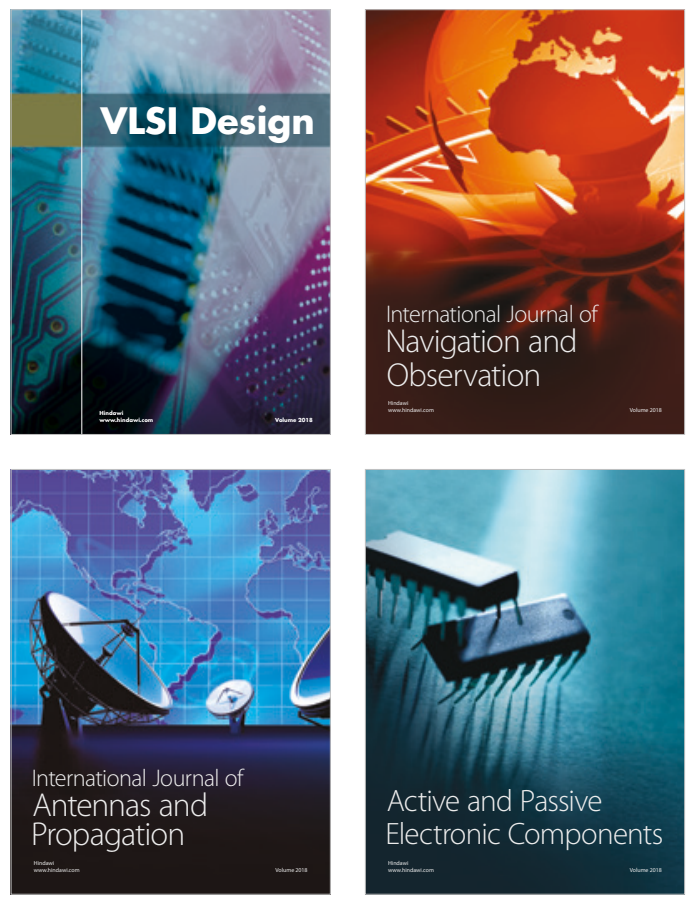
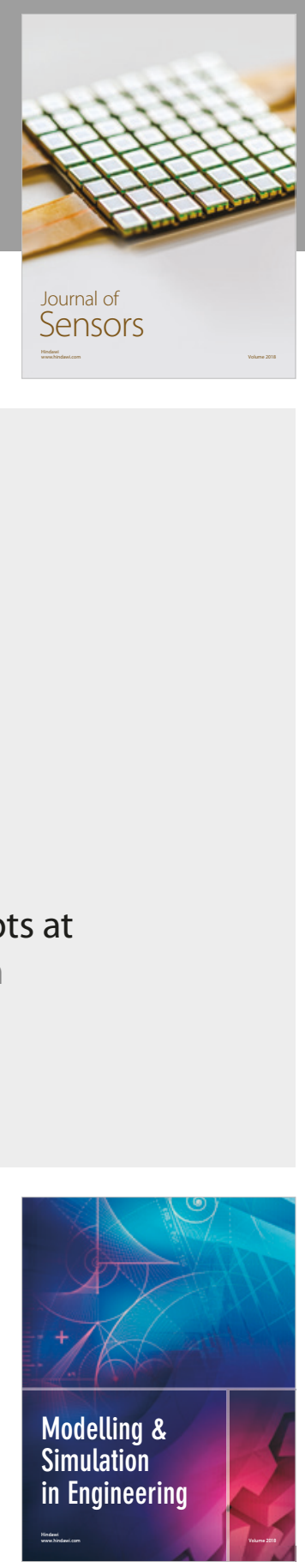

\section{Advances \\ Multimedia}
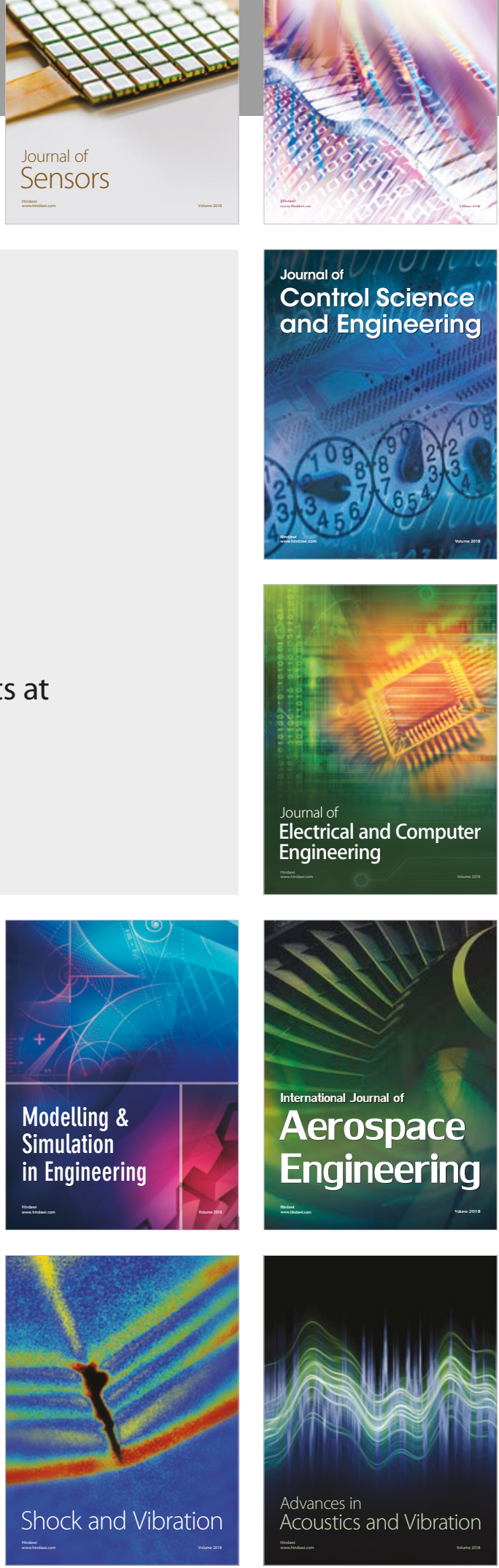